Драгица Кољанин

Универзитет у Новом Саду

Филозофски факултет

Одсек за историју

dragica.koljanin@gmail.com
Оригинални научни рад

примљено: 1. април 2012

прихваћено: 1. октобар 2012

\title{
ОБЛИКОВАЊЕ НОВОГ КОНЦЕПТА НАСТАВЕ ИСТОРИЈЕ У ОСНОВНИМ ШКОЛАМА У СРБИЈИ (1948-1952)*
}

Сажетак: На основу архивских истраживања, објављених извора и релевантне литературе и периодике представљене су расправе које су вођене у форумима Комунистичке партије Југославије, просветним органима и у стручној јавности о кључним питањима у извођењу наставе историје у основним школама у Србији. Током периода од 1948 до 1952. створен је нови концепт наставе историје, упоредо са увођењем обавезног осмогодишњег школовања.

Кључне речи: Југославија, Србија, Комунистичка партија Југославије, просветна политика, настава историје, уџбеници, основна школа.

Нека основна питања везана за извођење наставе историје у основним школама у социјалистичкој Југославији нису била решена ни неколико година после рата. Највећи проблем био је недостатак уџбеника историје, што је схваћено као последица недовољне „идејности“ историјске науке, односно чињенице да није извршена реинтерпретација резултата историјске науке у духу марксизмалењинизма (научног социјализма, односно дијалектичког материјализма). Највиши представници власти били су незадовољни основношколском наставом, уз остало и наставом историје због чега се настојало на што потпунијем усклађивању основношколске наставе са прокламованим циљевима друштвеног развоја. Из значаја који се придавао настави историје било је очигледно да је она добила велику улогу у стварање нове историјске свести у складу са новим идеолошким моделом и националном политиком. Када је реч о стручним питањима, главни проблеми били су у конципирању наставних програма у чему су се испољавале разлике међу републикама у методичком приступу настави историје.

\footnotetext{
* Текст је настао као фазни резултат рада на пројекту Војвођански простор у контексту европске историје (број 177002) Министарства просвете и науке Републике Србије.
} 
Комитет за школе и науку при влади ФНРЈ, савезни орган чији делокруг је била просветна политика, иницирао је крајем октобра 1947. расправу о резултатима наставе у основним школама, најављујући скуп који ће бити посвећен тој проблематици. ${ }^{1}$ Од 10. до 14. јануара 1948.у Београду у Комитету за школе и науку при Влади ФНРЈ одржана је конференција по питању основне наставе на којој су учествовали представници свих народних република ${ }^{2}$. Председник Комитета Маријан Стилиновић је нагласио да је то прва конференција савезног значаја „која поставља на дневни ред питања наставе у нашим основним школама“. ${ }^{3}$

Међу главним темама били су наставни планови и програми за основне школе, као и настава историје у основним школама о чему је реферат поднео Радован Теодосић. Један од његових основних ставова је био да наставни предмет историје треба да омогући да се „схвати огроман историски значај народног устанка 1941 год., значај стварања новог типа државе народне демократије, да се јасно сагледају револуционарни преображаји који су настали као последица доследне народне револуције и који сваким даном добијају све пунију садржину“. ${ }^{4}$ Он је критиковао гледиште „да је задатак наставе националне историје у основној школи да пружи ученицима продубљено, научно систематизовано знање о историјским чињеницама“. Тежећи томе, многи наставници користе средњошколске уџбенике и друге књиге и предају оно што ђаци узраста од 10-11 година они нису у стању да схвате. Теодосић је сматрао да је главни циљ наставе историје у основним школама „да на најкрупнијим, стожерним тачкама које су означиле прекретницу у историском кретању напред пружи најглобалнију линију развоја и да на том материјалу развије патриотизам младих генерација, осећање националног поноса на своју отаџбину, на њену славну прошлост и величанствене успехе у садашњости“.

Теодосић је приметио да ни у једном другом наставном предмету као у настави историје, наставници не осећају такву несигурност, па стога „многа ненаучна схватања историских чињеница, која су раније владала у историји, треба подвргнути најозбиљнијој ревизији“. Наставници немају уџбенике и изворе, стручну штампу и приручнике, тако да су препуштени сами себи. Усто они ни сами не познају градиво које обрађују. „Историја се обично диктира и деца уче из тако скрпљеног уџбеника са масом и наставникових и ученикових грешака“. На основу налаза инспекције, навео је бројне примере искривљавања и шаблинизовања. У духу идеологије новог доба, сматрао је да је један од главних проблема у настави историје „недостатак класног приступа“, наводећи и следеће примере. „При обради турског периода у нашој историји подвлачи се само национално, али се не истиче довољно класно угњетавање, не указује се на класну суштину турског војног

\footnotetext{
1 Архив Југославије(АЈ), Комитет за школе и науку при влади ФНРЈ (ознака фонда:315) 315-18-219.

2 АЈ, 315-26-94, Комитет за школе и науку при Влади ФНРЈ, Преглед рада конференције по питању основне наставе, одржане у Београду од 10. до 14. јануара 1948; види и: Endru Baruh Vahtel, Stvaranje nacije, razaranje nacije. Književnost i kulturna politika u Jugoslaviji, Beograd 2001, 169.

${ }^{3}$ AJ, 315-26-419, Радован Теодосић, Настава историје у основној школи.

${ }^{4}$ AJ, 315-26-419, Радован Теодосић, Настава историје у основној школи; види и: Савезна конференција учитеља, педагога и осталих просветних радника о основној настави, Просветни преглед, 2-3, 30. јануар 1948, 1-3.
} 
феудализма./.../ Затим грубо искривљавање градива: 'Југославијом је владао краљ, а сада влада Тито', 'Тито и Дража састали су се да поделе новац и оружје', 'Немци су напали нашу земљу, јер нису имали довољно земље за живот', /.../'Македонија је добила име по маку', 'Демократија је земља без краља, преме томе излази да и у Америци у којој нема краља, постоји демократија', 'Хрвати су гонили и убијали Србе после капитулације 1941 год.,'“. Теодосић је критиковао и вештачке аналогије са данашњицом којој су наставници често прибегавали јер „на тај начин грубо вулгаризују историско градиво, идеализирајући прошлост, идентификујући патриотизам прошлих генерација са патриотизмом данашњим, иако постоји квантитативна разлика између данашњег патриотизма и патриотизма из доба Косовског боја, првог и другог устанка, балканског и првог светског рата“. Критиковао је праксу поређења Пете офанзиве са Косовским бојем, Саве Ковачевића са Милошем Обилићем, Ситнице са Сутјеском. То је за њега био доказ „крајње примитивног схватања везе са савременошћу. Примери необичне храбрости хероја коју су показале хиљаде наших људи на фронту и у позадини за време народноослободилачке борбе не могу се објаснити само вековном тежњом нашег народа за слободом, још мање традиционалним цртама карактера нашег народа. Одлучујућу улогу у томе играло је нешто друго, ново: свест нашег човека, снажно морално-политичко јединство наших народа, њихова збијеност око Комунистичке партије./.../ Патриотизам и свест нашег партизана су далеко виши и дубљи од патриотизма и свести хајдучких и ускочких чета XVI, XVII и XVIII века“. Ипак, оценио је да је настава историје на вишем ступњу него пре рата . „Све је мање случајева десног застрањивања, мада се, као што смо видели наставници још нису у потпуности ослободили левих претеривања и вулгаризовања историског градива“. Да би се настава историје „поставила на правилну основу и искористиле њене ванредне могућности у образовно-васпитне сврхе“, Теодосић је предложио да се пре свега израде тезе у којима би се дала оцена и научно тумачење историјског градива на чему би се ангажовали историјска друштва и институти, као и најистакнутији јавни радници и највиши државни руководиоци. На тој основи треба израдити конспект уџбеника, а затим и сам уџбеник који мора бити беспрекоран у научном и педагошком погледу. Трећи предлог за закључак је био да се одмах изради приручник за наставнике који би допринео њиховом стручном уздизању и побољшању квалитета историјске наставе. Ради побољшања наставе историје, истакао је и значај наставних средстава, пре свега историјских филмова, албума, фотографија, карата и слично.

Теодосић је поменуо и разлике у распореду градива у програмима за наставу историје између Србије и других република. Због преопширности програма, у Србији су се после анкетирања наставника, определили за прогресивно хронолошки метод, док је у другим републикама коришћен принцип концентричних кругова. У вези са односом градива историје народа једне републике према историји народа других република, Теодосић је заступао мишљење да у програму наставе историје сваке републике у првом плану треба да буде историја дотичног народа. „Што из историје осталих република треба да уђе у програм појединих република, требало би да одреди свака република./../Опсег тога материјала свакако треба да се 
сведе на најкрупније појаве и догађаје на основу чега ће се моћи да формира код ученика свест о припадности широј домовини, схватање о братској заједници равноправних народа, о јединству и повезаности њихове судбине. И за ово градиво комисија би такође требало да изради тезе“. ${ }^{5}$

У дискусији поводом реферата Радована Теодосића учествовао је већи број учитеља и педагога из разних република. Иво Макек из Хрватске је прихватио оцену да је стање историјске наставе у нашим основним школама тешко пре свега због стања историјске науке, помањкања историјских уџбеника, мањкавости идеолошко-политичке изградње и стручне спреме наставника, као и тешких околности у којима многе основне школе раде. Он је бранио концепт концентричних кругова у распореду градива који је прихваћен у Хрватској. За разлику од Теодосића, Макек је сматрао да није довољно да се у уџбеницима само историјским причама изграђује историјска свест. Он се залагао за уџбеник „у коме ће свака метод.јединица, одређена програмом, бити изложена стварно и сажето, методски правилно и у дјеци доступној форми“. Расправа се водила и о обиму градива намењеног ученицима, пре свега трећег разреда, као и дилеми да ли они могу да усвоје тако обимно градиво.

Како је највећи део школске деце још увек био обухваћен само четворогодишњим школовањем, није било дилеме о томе да је потребна настава историје и у трећем и у четвртом разреду. Истовремено, показале су се разлике између појединих република у вези са распоредом градива (прогресивно хронолошки или концентрични кругови), обимом и карактером историјског градива и неким другим питањима. Више учесника у расправи наводило је примере искривљавања или вулгаризације историјских садржаја што је објашњавано непознавањем закона друштвеног развитка. Представници националних мањина су такође истицали тешкоће у раду због недостатка уџбеника. Ипак, није било дилеме о томе да мањине треба да уче историју народа ФНРЈ јер су они њени грађани. Они треба да у њу уклопе битне моменте из историје своје мањине, „али не историју народа своје матице ван граница наше земље“.

У дискусији о настави историје учествовала је и Митра Митровић, министар просвете у влади Србије. Она је устврдила да је после ослобођења васпитање деце у школама било усклађено са тековинама народноослободилачке борбе чему су највише допринели учитељи, који су већином правилно политички орјентисани. Истакла је да није довољна само ревизија историје и да је то посао научника историчара. Уџбеници историје не постоје, а наставници настоје да историју предају научно због чега се сматра да све што је национално је прошлост. Тако су они отишли „у једно друго исто тако крупно скретање, те историју своде на извесне круте социолошке шеме, претстављајући извесна апстрактна излагања друштвено економска, па онда у те калупе без довољно научности трпају догађаје и људе. То је у главном основно скретање у тумачењу историских догађаја, које бојим се да се не пренесе и у уџбенике“.

\footnotetext{
${ }^{5}$ АЈ, 315-26-420 до 431, Радован Теодосић, Настава историје у основној школи.
} 
Митра Митровић је посебну пажњу посветила кључном питању: односу општег, југословенског и посебног, националног. „Да истакнем још један моменат у погледу историје. То је проблем Југославије, мислим да је то један од крупних наших проблема у вези са наставним планом, програмом и уџбеницима. Сасвим је правилно да се деци мора пре свега приказивати историја своје нације, јер је то детету приступачно и јер дете треба да позна своју националну прошлост. Али ми педагози и практичари морамо се замислити, како да у васпитању наше деце решимо проблем Југославије у историји и земљопису или на којој другој научној области. Ми треба да створимо деци појам о Југославији као земљи социјализма, као својој отаџбини. Међутим, бојим се да смо ми мало сузили ствари и да мало сувише пледирамо на тим националним моментима, што је правилно, али није усклађено са нужносшћу да се створи појам о Југославији, да деца у Југославији виде нешто своје, блиско и присно, своју домовину коју ће волети и која треба да му буде најближа. У нашем плану и програму као и у нашим уџбеницима, ја не говорим о братству и јединству, него о Југославији као држави нашој и отаџбини нашој-остало је питање Југославије довољно необрађено“.

Један од закључака конференције је био да у посебним комисијама треба продискутовати „питање наставе и садржаја природописа, географија и историје, пошто досадашњи наставни програми, као и уџбеници, не задовољавају“. ${ }^{6}$

У складу са захтевом конференције о основној настави, Комитет за школе и науку при Влади ФНРЈ известио је републичка министарства просвете о намери да изради приручник за предавања историје у основној школи. „Како настава историје задаје највише бриге учитељима основних школа, то ће овај приручник помоћи учитељима да правилно тумаче историске догађаје. За израду овог приручника потребно је да свака народна република према својим могућностима разради један део програма““7. У допису упућеном Министарству просвете Србије, савезни Комитет за школе и науку предложио је да стручњаци у Србији обраде 16 тема из оквирног програма за III и IV разред основне школе. Наглашено је да ће то бити приручник за наставнике, а не за ученике. Из оквирног програма за III разред предложене су следеће теме: 1.Наша домовина; 2. Живот људи у најстарије доба; 3.Стари Словени и њихово доба; 4.Һирило и Методије; 5.Јужнословенске државе; 6.Турска освајања јужнословенских земаља; 7.Јужни Словени под турском влашћу и отпор наших народа. Из оквирног програма за IV разред предложене су следеће теме: 8.Први и други српски устанак; 9.Културне прилике у првој половини XIX века; 10. 1848 година-раднички покрет; 11. Балкански ратови; 12. Први светски рат; 13. Октобарска социјалистичка револуција; 14.Наши народи од 1918. до 1941. године; 15. Народноослободилачка борба; 16. Федеративна Народна Република Југославија.

На основу захтева постављених на конференцији о основној настави, у стручним часописима објављивани су чланци са упутствима како треба предавати историју у основним школама на основу постојећег наставног плана и програма.

\footnotetext{
${ }^{6}$ AJ, 315-26-416.

${ }^{7}$ AJ, 315-24-452.
} 
Ови чланци су требали да буду засновани на реинтерпретацији историјских садржаја и односили су се на раније историјске периоде. ${ }^{8}$

Министарство просвете Србије припремило је предлог наставног плана и програма за основне школе и упутило га на одобрење савезном Комитету за школе и науку. Министарство за просвету Србије покушало је изврши неке измене у оквирном наставном плану и програму, али то није наишло на разумевање савезне установе. У набрајању задатака историје Министарство просвете Србије је изоставило пасус у којем се као један од задатака историје наводило „развијање непомирљиве мржње према непријатељима отаџбине“. Комитет је одобрио овај наставни план и програм али је тражио да се овај пасус врати јер је изузетно важан за правилно васпитање младе генерације. „Из задатака наставе историје изостављен је врло важан пасус који је у оквирном наставном програму постављен, а то је: 'да развија непомирљиву мржњу према непријатељима отаџбине, према свима онима који раде против тековина народно-ослободилачке борбе'. Ово је толико важан моменат, да се ни у ком случају не може изоставити и треба га унети у задатак историске наставе. Нашу децу треба одгајати тако да постану непоколебљиви борци у одбрани своје слободне отаџбине, а један од начина је и развијање непомирљиве мржње према нашим непријатељима“. ${ }^{9}$ У објављеном наставном плану и програму враћен је поменути пасус о задацима наставе историје, али је донекле измењен. „З. Да учвршћује и даље развија братство и јединство и остале тековине Народнослободилачке борбе и да развија непомирљиву мржњу према империјалистима и осталим непријатељима домовине“. ${ }^{10}$

Уваживши примедбе савезног Комитета за просвету и науку, Министарство просвете Србије донело је 1948. нови наставни план и програм за основне школе. ${ }^{11}$ У складу са препорукама Комитета за школе и науку, додат је још један наставни предмет, ручни рад. Број часова историје у трећем разреду смањен је са три на два (8,3\% од укупно 24 часа) недељно. У четвртом разреду број часова историје остао је исти, четири часа (15,4\% од укупно 26 часа) недељно. Задржан је принцип хронолошко прогресивног излагања. У програму за трећи разред дата је уводна тема Наша домовина-Зашто изучавамо историју наше домовине, а затим следе теме од Живота људи у најстарије доба до Борбе Црногораца за ослобођење чиме је програм за трећи разред хронолошки продужен.

Програм историје за четврти разред хронолошки је обухватао период од Првог српског устанка до историје ФНРЈ. Историји Југославије посвећене су три обимне теме са великим бројем наставних јединица. У теми 10. Наши народи од 1918. до 1941. године биле су следеће наставне јединице: Аграрно и национално питање, Незадовољство народних маса монархијом и капиталистичким државним

\footnotetext{
${ }^{8}$ Dušan Perović, Teze za srpsku istoriju, Savremena škola, 7-8, 1948, 19-30.; isti, Teze za srpsku istoriju, Savremena škola 9-10, 1948, 1-13; Teze za makedonsku istoriju, Savremena škola, 1, 1949, 7-16; Teze za slovenačku istoriju, isto, 17-30;

${ }_{9}^{9}$ АЈ, 315-24-283, Комитет за школе и науку при Влади ФНРЈ, Министарству просвете НР Србије, 3 јун 1948.

${ }^{10}$ Наставни план и програм за основне школе, Београд 1948, 20.

${ }^{11}$ Исто.
} 
уређењем, Борба радничке класе и сељаштва, Обзнана и Закон о заштити државе, 6јануарска диктатура, Народни фронт, улога Комунистичке партије, петоколонашки режими, фашизам, Други светски рат, пакт и 27 март, (6 часова). Тема 11, Народноослободилачка борба састојала се од следећих наставних јединица: Напад на Југославију, издаја, капитулација, Окупација и цепање земље, Немачки напад на СССР, Почетак устанка, Комунистичка партија Југославије на челу са Маршалом Титом, инспиратором и организатором НОБ, Издајници народа и њихова сарадња са окупатором. Прва, друга и трећа офанзива, Прво заседање ABHOJ-а, Четврта и пета офанзива, Друго заседање АВНОЈ-а, Шеста и седма офанзива, Ослобођење земље, Улога и значај СССР у Другом светском рату, (10 часова). У теми 12. Федеративна Народна Република Југославија биле су следеће наставне јединице: Национална равноправност и федеративно уређење, Братство и јединство наших народа, Народна власт, Комунистичка партија Југославије, Народни фронт, Народна армија, Устав, Обнова и изградња наше земље, Друштвено-економска основа наше државе, Аграрна реформа и национализација великих предузећа, Петогодишњи план (8 часова).

Показало се да је наставни план из историје за трећи, а нарочито за четврти разред основне школе био веома опширан и захтеван. Било је тешко очекивати да га могу успешно савладати и учитељи и ученици јер и даље није било уџбеника за ученике ни приручника за наставнике. Вероватно је опширност програма била разлог што је предвиђено да после једног часа предавања новог градива следе два часа утврђивања и понављања. Од укупно 132 часа историје у четвртом разреду, 46 часа $(34,8 \%)$ су била за предавање новог градива, а 86 часова (65,2\%) за утврђивање и понављање. Већи део часова био је посвећен историји Југославије, пре свега историји НОБ и историји ФНРЈ. Од 46 часова предвиђених за излагање новог градива, историји Југославије је посвећено 24 (52,2\%), од тога 16 часова (34,8\%) је било посвећено историји НОБ и историји ФНРЈ.

У складу са дискусијама и закључцима Конференције о основном образовању из јануара 1948, саставни део наставног плана и програма је било Објашњење уз програм наставе историје. То је објашњено потребом за „идејнополитичким васпитањем омладине“ и за научним осветљавањем историјског градива. На основи задатака наставе историје дато је неколико опширних напомена. Истакнуто је да нису сви периоди историје подједнако важни тако да неки могу и да се испусте. Посебно се наглашавао значај улоге личности у историји, али се указивало на честу грешку да се личности да сувише велики значај. Тражило се да се избегну историјске аналогије и наведене су неке од њих: хајдуци и партизани, пораз Турака под Бечом и Стаљинградска битка, устанак у Орашцу 1804. и народни устанак 1941, Карађорђе и Тито. Морала је да се прави разлика између ослободилачких и освајачких ратова при чему је истакнуто да је „Народноослободилачка борба, по замаху, степену организованости, начину на који је вођена, коначним циљевима ради којих је вођена и извојеваним тековинаманајправеднији рат који су наши народи водили за своје ослобођење““12 Посебни

${ }^{12}$ Исто, 27. 
захтеви постављени су пред наставника. Он „не сме имати неутралан- равнодушан и хладан однос, јер се таквим ставом не може пробудити емоционални однос ученика према историским догађајима и личностима. /.../ Народноослободилачку борбу треба продубљивати и даље развијати на примерима социјалистичке изградње наше земље повезујући чврсто историјско градиво са данашњицом. Али патриотизам се не мери речима, него делима/.../ Према томе, поред развијања емоционалног односа ученика према догађајима и личностима прошлости треба ићи корак даље-вежбању и навикавању ученика да од речи прелазе на дела“. У вези са односом националне историје и историје других југословенских народа, тражено је да се „на исти начин обухвати и историја осталих народа повезујући најтешње то градиво с одговарајућим градивом српског народа““. ${ }^{13}$

Просветна политика је била један од приоритета Комунистичке партије Југославије, односно њених органа задужених за ту област. То су пре свега биле агитпроп комисије разних нивоа, међу њима и највишег, Управе за пропаганду и агитацију при Централном комитету КПЈ. ${ }^{14}$ Конференција о основношколској настави одржана јануара 1948.jе показала да партијски органи нису били задовољни идејном основом наставе, уз остало и схватањем историје, као и тиме како се изводи настава историје у школама и на факултетима. То је поновљено и на највишем нивоу, на Петом конгресу КПЈ јула 1948. сазваном у драматично време распламсавања сукоба Југославије са земљама источног блока на челу са Совјетским Савезом.

У Извештају о агитационо-пропагандном раду Централног комитета Комунистичке партије Југославије ${ }^{15}$ поднетом на Петом партијском конгресу, руководилац Управе за пропаганду и агитацију и један од првака КПЈ Милован Ђилас, је значајну пажњу посветио просвети. Он је навео да је створен државни просветни апарат, као и нови школски систем основног, средњег и вишег образовања, а да је број школа надмашио онај од пре рата. Као главну слабост школа истакао је „слабости идеолошког карактера. У нашим школама и на универзитетима још увијек се наши ђаци и студенти трују идеализмом, мистицизмом, ненаучним, антимарксистичким схватањима историје, књижевности, језика, правних наука итд. Узроци ових слабости у нашим школама и универзитетима леже у наслијеђеном, криво васпитаваном и дјелимично непријатељском наставничком кадру, дакле-у немању идеолошки чврстог и спремног кадра, у помањкању марксистичко-лењинистичких уџбеника, нарочито из области националних предмета и у недовољној борби неких партијских радника за наставу у нашим школама на марксистичким идеолошким основама.“16

\footnotetext{
${ }^{13}$ Исто, 29.

${ }^{14}$ Ljubodrag Dimić, Agitprop kultura. Agitpropovska faza kulturne politike u Srbiji 1945-1952, Beograd 1988, passim.

${ }^{15}$ Милован Ђилас, Извештај о агитаиионо-пропагандном раду Централног комитета Комунистичке nартије Југославије, реферат одржан на V конгресу КПЈ, Београд 1948; исто у: V kongres Komunističke partije Jugoslavije, izveštaji i referati, Beograd 1948, 253-305.

${ }^{16}$ Исто, 29-30.
} 
Ђилас је истакао и задатке који стоје пред комунистима при чему је значајну улогу наменио проучавању историје: „У наредном периоду у нашој идејнополитичкој борби за јачање и учвршћење јединства народних маса Југославије нарочито мјесто треба да има -питање југословенског социјалистичког патриотизма. У чему је садржина тога питања? Подизати наше радне људе у духу новог, југословенског патриотизма- то значи вршити мобилизацију за изградњу социјализма код нас. Нема социјализма без социјалистичког патриотизма. /.../ У подизању и развијању новог, југословенског патриотизма морамо савлађивати и савладати озбиљне препреке. Те се препреке прије свега, састоје у јаким, жилавим остацима српског, хрватског, словеначког итд. буржоаског национализма. Буржоаски национализам још увијек даје отпор и у области привреде, и у области политике, и у области културе./.../ С друге стране, било би штетно ако би се борба против остатака буржоаског национализма схватила као стварање неког 'југословенства' које укида националне осјећаје српског, хрватског, словеначког, македонског и црногорског народа и не води рачуна о тим осјећајима. Нови југословенски патриотизам укључује у себе љубав према својој ужој домовини, конкретно се изражава кроз њу. Основу нашег новог социјалистичког, југословенског патриотизма мора претстављати рад на историји наше партије, на историји нашег радничког покрета, на историји Народноослободилачке борбе. Без теоретског и историјског освијетљавања ослободилачке борбе радних маса Југославије, није и не може бити потпуно идеолошко подизање Партије и народа./... Пред нама стоји-у најужој вези с горе реченим-и проблем историје народа Југославије, историје књижевности и умјетности народа Југославије, историје наше друштвене мисли, укратко проблем марксистичког освијетљавања свих области живота наших народа у прошлости“. ${ }^{17}$

И поред оштрих критика највиших партијских форума, стање у извођењу наставе историје у основним школама није се много изменило ни током 1949. И даље се стално истицало да је највећи проблем недостатак уџбеника историје, а истицали су се и резултати у достизању „идејности“ у настави историје. Према анализи Министарства за науку и културу Владе ФНРЈ „настава историје у нашој основној школи по свом квалитету, научности и идејној усмерености несумњиво је изашла из старих оквира. Учитељи траже помоћ, служе се материјалом, труде се да правилно протумаче догађаје из историје, али је поред свега тога стање ове наставе у основној школи данас врло тешко./.../ Због тога је и помоћ историчара, стручњака у изради уџбеника историје, а поготово програма за основну школу била минимална како у погледу периодизације, тако и у погледу избора наставног градива, у погледу постављања појединих одељака, у погледу распореда, система./../ За наставу историје у основној школи не постоји данас никакав уџбеник ни у једној нашој републици. Народна република Србија покушала је од ослобођења до данас у три маха да изради овај уџбеник. Први комисијски покушај одбачен је као неуспео. Рад Бранка Ћопића такође није задовољио. Почетком 1949. под руководством друга

\footnotetext{
${ }^{17}$ Исто, 33. Своја схватања о улози историје и историчара Ђилас је детаљно експлицирао у свом чланку О националној историји као васпитном предмету, Историјски гласник, 1, 1949, 3-20.
} 
Душана Перовића, члана Наставног савета НР Србије учињен је и трећи покушај. Овај материјал налази се у рукопису и није још дефинитивно прегледан. Према томе, потребно је хитно приступити изради уџбеника историје за основне школе. Ми смо мишљења да би требало израдити посебан уџбеник за сваку народну републику“. ${ }^{18}$

Велики значај у реформи просветног система имао је Трећи пленум Централног комитета КПЈ одржан 29. и 30. децембра 1949. ${ }^{19}$ Пленум је био посвећен проблему школства, али је имао и много шири значај у стварању југословенског социјалистичког друштвеног модела. То је био период сукоба са источним блоком који је све више попримао идеолошку димензију. Културној и просветној политици стављено је у задатак да васпитава „слободне социјалистичке људе, људе који смело и одважно мисле и раде, који су широки и разноврсни у схватањима, а не људи чији ће умови бити подшишани на исти начин““20.

На пленуму је најављен постепен прелаз на осмогодишње обавезно основно школавање. Подносилац главног реферата Милован Ђилас је изнео бројне слабости у организовању наставе које су чланови партије били дужни да исправе. Наставне планове и програме је требало довести „у склад са нашом генералном линијом у настави, с нашим општим циљевима, а такође и с нашим читавим системом школства и нашим конкретним потребама“. Наставни планови су преопширни и треба их смањити на оно што је најбитније. У вези са питањем да ли треба у основним школама осим своје, изучавати и историју народа Југославије, он је истакао да је то потребно. ${ }^{21}$ У дискусији о питањима која су поменута у Ђиласовом реферату, истакнути су разни проблеми у настави, па и у настави историје где су помињани примери вулгаризације. „Професори, у жељи да сваку ствар протумаче дијалектички, доводе просто до смешних ситуација. Тако је један од њих тумачио да је цар Лазар изгубио битку само зато што није познавао марксистичку стратегију и тактику. “22

У резолуцији Трећег пленума ЦК КПЈ као задаци су истакнути “израда, допуњавање и поправљање наставних програма“. Тражило се да се они ослободе опширности и сувишности. По питању уџбеника тражило се да се уместо преведених (совјетских) израде сопствени уџбеници, пре свега из друштваних наука. $^{23}$

После Трећег пленума ЦК КПЈ и почетка процеса децентрализације и дебирократизације осетиле су се промене у разним областима друштвеног живота. Одвајање од совјетског модела, односно критика совјетске друштвене мисли и науке, смањено превођење и објављивање научних књига, уџбеника и приручника из Совјетског Савеза, отварали су простор развоју научног живота у Југославији. То се осетило и у југословенској педашкој науци. За наставу историје посебно је био

\footnotetext{
${ }^{18}$ Културна политика Југославије, књ.1, 375-377.

${ }^{19}$ Lj. Dimić, Agitprop kultura, 241-244.

${ }^{20}$ Sednice Centralnog komiteta KPJ (1948-1952), 295-296; Lj. Dimić, Agitprop kultura, 241-244.

${ }^{21}$ Sednice Centralnog komiteta KPJ (1948-1952), 286, 297, 299, 303, 370.

${ }^{22}$ Sednice Centralnog komiteta KPJ (1948-1952), 359.

${ }^{23}$ Исто, 483-485.
} 
важан приручник Јосипа Демарина Методика наставе повјести (Загреб 1951). Аутор се посебно бавио наставом историје у основним школама, а једно од централних питања био је однос историје као науке и као наставног предмета. Књига је веома позитивно оцењена у стручној јавности. ${ }^{24}$

Ради спровођења резолуције пленума ЦК КПЈ о школству, Министарство просвете Србије је организовало обилазак основних школа у појединим деловима републике да би се упознало са стањем наставе и чуло примедбе учитеља и наставника. Заменик министра просвете Србије Коста Грубачић је од 8. до 25.марта 1950. обишао већи број школа у западној Србији, затим и у делу Босне и Херцеговине. Он је закључио да је због недостатка уџбеника историје за трећи и четврти разред „нужно издати неки привремени приручник, бар за учитеље“. ${ }^{25}$ Био је незадовољан стручном спремом учитеља, али не само њом. "По питању идеолошко-политичке изградње и на конференцијама и у индивидуалном раду постоји још већа незаинтересованост код учитеља и у још већем броју него је то случај са стручном изградњом. Дискусија је или слаба или је и нема“. Похађање основне школе било је добро (96\%), али су били чести изостанци од почетка пролећа. Постојао је проблем недостатка школског простора, а школе су оскудевале и у најпотребнијим наставним средствима. „Снабдевање писаћим прибором (бележницама, оловкама итд) још увек не задовољава. Нарочито слабо стоји по питању оловака. Школе добијају недовољан број оловака, тако да једну оловку деле понегде на двојицу, а понегде и на тројицу ђака“. ${ }^{26}$

Настава историје у основним школама у Србији 1945-1952.

\begin{tabular}{|c|c|c|}
\hline \multirow{2}{*}{ Године } & \multicolumn{2}{|c|}{ Разреди } \\
\hline & III & IV \\
\hline 1945 & 3 & 4 \\
\hline 1947 & 3 & 4 \\
\hline 1948 & 2 & 4 \\
\hline 1949 & 2 & 4 \\
\hline 1950 & 2 & 2 \\
\hline 1952 & 2 & 2 \\
\hline
\end{tabular}

Пола године после одржавања Трећег пленума, јуна 1950. Агитпроп ЦК КПЈ је извршио анализу спровођења његових закључака. Установљено је да је започео процес децентралзације школства и стварања услова за прелазак на осмогодишње школовање, али да на питању растерећивања наставних планова и

\footnotetext{
24 Златибор Поповић, Методика наставе повјести од Јосипа Демарина, Настава и васпитање, 5, 1952, 358-400.

${ }^{25}$ AJ, 315-22-146 do 156, Извештај са обиласка НР Србије-Титовоужичке области-и НР Б и Х-једног дела Сарајевске и Тузланске области-у времену од 8. до 25. ІІІ 1950. г.

${ }^{26}$ Исто.
} 
програма није много учињено. ${ }^{27}$ Агитпроп ЦК КПЈ није био задољан ни стањем историјске наставе на Филозофском факултету у Београду, од којег се очекивало да буде организатор посла на писању историје Југославије. Показало се да се на овом факултету програм изучавања историје Југославије завршава 1941.годином. Следила је оштра оцена наставног кадра, установљено је да студенти немају одакле да уче историју, или да је уче према неподобним књигама. „Катедру за историју држе буржоаски орјентисани наставници. /.../ Нема ни уџбеника ни скрипата./.../ Период Народноослободилачке борбе предаван је досад (за четири године) свега један час у летњем семестру 1946-1947. године. Студенти овај предмет спремају по књизи Владимира Ћоровића-Историја Југословена““ ${ }^{28}$

После захтева партијског руководства да се изврши растерећивање наставних програма и њихово прилагођавање узрасту ученика, Министарство просвете Србије је у новом наставном плану и програму за основне школе за школску 1950/1951.годину ${ }^{29}$ извршило значајне промене. Оптерећење ученика је смањено, тако да је и у трећем и у четвртом разреду укупан недељни фонд часова био по 24. Број часова историје у трећем разреду је остао исти, 2 (8,33\% од 24) недељно, али је број часова историје у четвртом разреду преполовљен, на 2 часа недељно. Напуштен је хронолошко прогресивни принцип, тако да се сада настава историје и у Србији заснивала на принципу концентричних кругова.

У програму за трећи разред наглашавао се значај завичајне историје, која је представљена као први корак у разумевању историјских токова и догађаја. Наставне теме су дате често само као епизоде без чвршће међусобне везе. Период између Првог српског устанка и деловања Вука Караџића није обухваћен ни једном темом. Од 15 наставних тема, њих 5, односно једна трећина је била посвећена историји Југославије која је приказана само преко историје Народноослободилачке борбе.

Теме у програму за трећи разред су биле следеће: 1.Историја завичаја. 2. Живот људи у најстарије доба. 3. Живот Словена у старој постојбини. 4. Јужни Словени у новој домовини. 5. Живот српског народа (племића и сељака) за време цара Душана. 6. Маричка битка; Краљевић Марко. 7.Косовски бој. 8. Хајдуци и ускоци. 9. Бојеви у првом и другом устанку.10. Вук Караџић. 11. Устанак у Србији 7 јула 1941. 12.Прелаз преко Неретве у IV офанзиви. 13. Напад на Дрвар. 14. Народни хероји из Народноослободилачке борбе. 15. Маршал Тито.

Због захтева да се наставни садржај у трећем разреду приближи узрасту ученика, у упутствима уз овај наставни програм тражено је да се користе и легенде, предања, народне песме, приче. У методској јединици Народни хероји препоручено је да се представе две личности: Иво Лола Рибар и Сава Ковачевић, „и још неког познатијег народног хероја“. ${ }^{30}$

\footnotetext{
${ }^{27}$ Спровођење Резолуције III пленума ЦК КПЈ о задацима у школству, Београд, јун 1950, Културна политика Југославије, књ.2, 318-320.

${ }^{28}$ Исто, књ. 1, 524-525.

${ }^{29}$ Наставни план и програм за основне школе за школску 1950/51 годину, Београд 1950.

${ }^{30}$ Исто, 10-13.
} 
У наставном програму за четврти разред обрађиване су следеће теме: 1. Стари Словени. 2. Живот наших народа од доласка на Балканско полуострво до пада под Турке (од стварања првих држава до Маричке и Косовске битке). 3. Живот наших народа под Турцима. 4. Сељачке буне: Матија Губец. 5. Први и Други српски устанак. 6. Балкански рат. 7. Светски рат; а) узроци и зараћене силе, сарајевски атентат, Церска и Сувоборска битка, б) повлачење преко Албаније, Солунски фронт и учешће Југословена из Аустро-Угарске у борби за национално ослобођење, в) Версаљски мир и стварање старе Југославије. 8. Живот наших народа у старој Југославији: тежак положај наших народних маса, незадовољство монархијом и друштвеним поретком, улога КПЈ у борби против реакционарних режима и фашизма. 9. Ослободилачки рат и стварање нове Југославије: а) Други светски рат, приступање Југославије тројном пакту и 27 март; б) напад Хитлеровске Немачке на Југославију, издаја, капитулација, окупација, цепање земље, домаћи издајници у служби окупатора; в) КПЈ-организатор отпора и борбе против окупатора и руководилац народне револуције; г) непријатељске офанзиве и жаришта народног отпора у Србији (Јабланица, Црна Трава, Космај, источна Србија, Срем); д) коначно ослобођење Југославије, сарадња са Црвеном армијом, допринос борбе народа Југославије војничком слому фашизма, тековине ослободилачког рата. ${ }^{31}$

За разлику од дотадашње праксе када је све планове и програме за основне школе објављивало Министарство просвете Србије, наставни план и програм за школску 1951/1952.годину објавио је Савет за просвету, науку и културу НР Србије. ${ }^{32}$ Нови наставни план и програм био је идентичан претходном, али су му приложена много детаљнија објашњења за учитеље. Од наставника се очекивало велико ангажовање не само у извођењу наставе историје у самој школи, него и у друштвеној средини. За сваку тему дата су посебна упутства за обраду и литература која ће послужити за припрему часа. То су углавном била дела марксистичке литературе (Енгелс, Сегал, Островитјанов).Иако нису постојали уџбеници, тражило се да наставници не диктирају градиво. Они су требали да га оживе сликама, цртежима, текстовима, а дата су и нека друга дидактичка упутства.

И поред сталних захтева највиших партијских и државних органа, затим жалби учитеља и наставника, као и више пута поновљених конкурса, школски уџбеници за наставу историје у основним школама Србије нису се појавили све до раних педесетих година. И ти први уџбеници који су прихваћени за употребу у школама штампани су као рукописи. Они су написани на основу прописаних наставних планова и програма. Током 1952. године објављени су уџбеници за трећи и за четврти разред основне школе, који су затим више година били у употреби. ${ }^{33} \mathrm{y}$

\footnotetext{
${ }^{31}$ Исто, 11-12.

${ }^{32}$ Наставни план и програм за основне школе за школску 1951/52 годину, Београд 1951.

${ }^{33}$ Историја за III разред основне иколе, (Београд 1952) Goluba Janjuševića objavljivana je do 1959, a Историја за IV разред основне школе (Београд 1952) Miljkana Todorovića do 1958. godine. Ovi udžbenici su prevođeni na mađarski jezik i korišćeni su u osnovnim školama za mađarsku nacionalnu manjinu.
} 
стручној јавности ови уџбеници су критиковани, али углавном из идеолошког угла. ${ }^{34}$

\section{Извори и литература:}

Извори:

Архив Југославије(АЈ),

Комитет за школе и науку при влади ФНРЈ (ознака фонда:315) 1946-48

Културна политика Југославије 1945-1952. Зборник докумената, приредили Бранка Докнић, Милић Ф. Петровић, Иван Хофман, књ.1-2, Београд 2009,

Наставни план и програм за основне школе, Београд 1948.

Наставни план и програм за основне школе за школску 1950/51 годину, Београд 1950.

Наставни план и програм за основне школе за школску 1951/52 годину, Београд 1951.

V конгрес Комунистичке партије Југославије, извештаји и реферати, Београд 1948.

Седнице Централног комитета КПЈ (1948-1952), приредили Бранко Петрановић, Ранко Кончар, Радован Радоњић, Београд 1985.

Савезна конференција учитеља, педагога и осталих просветних радника о основној настави, Просветни преглед, 2-3, 30.јануар 1948.

\section{Литература:}

Vahtel, Endru Baruh, Stvaranje nacije, razaranje nacije. Književnost i kulturna politika u Jugoslaviji, Beograd 2001.

Димић, Љубодраг, Агитпроп култура. Агитпроповска фаза културне политике у Србији 1945-1952, Београд 1988.

Ђилас, Милован, Извештај о агитаиионо-пропагандном раду Централног комитета Комунистичке партије Југославије, реферат одржан на V конгресу КПЈ, Београд 1948.

Ђилас, Милован, О националној историји као васпитном предмету, Историјски гласник, 1, 1949, 3-20.

Живковић, Владимир М., Два уибеника историје за основне школе, Настава и васпитање, 5, 1952, 292-298.

Јањушевић, Голуб, Историја за ІІІ разред основне школе,Београд 1952.

Перовић, Душан, Тезе за српску историју, Савремена школа, 7-8, 1948, 19-30.

Перовић, Душан, Тезе за српску историју, Савремена школа 9-10, 1948, 1-13.

Поповић, Златибор, Методика наставе повјести од Јосипа Демарина, Настава и васпитање, 5, 1952, 358-400.

Тезе за македонску историју, Савремена школа, 1, 1949, 7-16.

Тезе за словеначку историју, Савремена школа, 1, 1949, 17-30.

Тодоровић, Миљкан, Историја за IV разред основне школе,Београд 1952.

\footnotetext{
${ }^{34}$ Владимир М. Живковић, „Два уџбеника историје за основне школе“, Настава и васпитање, 5, 1952, 292-298.
} 


\title{
DRAGICA KOLJANIN
}

\section{FORMING A NEW CONCEPT OF TEACHING HISTORY IN ELEMENTARY SCHOOLS IN SERBIA (1948-1952)}

\begin{abstract}
Summary
The highest representatives of the authorities in Yugoslavia and Serbia after the World War II were dissatisfied with the elementary school teaching, including the history teaching. Therefore, there were attempts to thoroughly align elementary education with the proclaimed goals of the social development. Taking into consideration the importance given to the history teaching, it was evident that it got a major role in the creation of a new historical awareness in accordance with the new ideological model and the national politics. Concerning the expert issues, the main problems were in designing of curricula, where there were demonstrated differences among the republics in the methodical approach to the history teaching in elementary schools. In January 1948, Committee for Schools and Science within the FNRY Government organized a conference on elementary school teaching, in Belgrade. Curricula for elementary schools, including the history teaching, were among the main topics of the conference. Within the history teaching, there were differences in the arrangement of lessons (progressive chronological or concentric circles), the scope and nature of historical teaching material, and some other issues. Dissatisfaction with the history teaching in elementary schools, primarily with its "conceptuality", was presented at the Fifth Congress of the Communist Party of Yugoslavia in July 1948. However, by 1952 the concept of the history teaching was fully established in the curricula, both in its content and the methodological-didactic sense. The same year, there were published the first elementary-school history textbooks, which provided a complete and relatively consistent view of history, especially the most recent one. There was established a concept according to which the focus of the history was on the present, which was a guideline for the future, while the most recent past was used mainly as a negative example.
\end{abstract}

Keywords: Yugoslavia, Serbia, the Communist Party of Yugoslavia, educational policy, history teaching, textbooks, elementary school. 